\title{
Analiza semantyczno-składniowa wybranych jednostek z segmentem wystarczy
}

Słowa klucze: wystarczy; jednostka języka; semantyka; składnia; czasownik Keywords: wystarczy; lexical unit; semantics; syntax; verb

1. Przedmiotem zainteresowania w prezentowanym artykule są wybrane jednostki języka ${ }^{1}$ zawierające segment wystarczy. O ile mi wiadomo, żadna z nich nie była dotychczas przedmiotem osobnej analizy. Pewne uwagi na temat wyrażeń z wystarczy można znaleźć w niektórych pracach gramatycznych (np. Szupryczyńska 1996; Saloni, Świdziński 1998) oraz semantycznych (np. Wierzbicka 1966; Bogusławski, Wawrzyńczyk 1993; Bogusławski, Danielewiczowa 2005), przy czym podstawowy problem w wypadku wszystkich tych prac stanowi moim zdaniem niewłaściwa delimitacja jednostek języka (Bogusławski, Wawrzyńczyk 1993; Bogusławski, Danielewiczowa 2005), mieszanie ze sobą użyć różnych jednostek języka z segmentem wystarczy, traktowanie ich jako użycia jednej jednostki (Szupryczyńska 1996) oraz opieranie rozważań wyłącznie na konstrukcjach eliptycznych (Szupryczyńska 1996, Apresjan 1995). Celem tego artykułu jest analiza składniowo-semantyczna czterech - jak sądzę - najprostszych spośród ośmiu

1 Terminu ,jednostka języka” używam zgodnie z rozumieniem, jakie nadał mu Andrzej Bogusławski (Bogusławski 1976 i 1998). 
wyróżnionych przeze mnie jednostek języka współtworzonych przez ciąg wystarczy, a mianowicie: coś ${ }_{a}$ wystarczyło, żeby $p$; wystarczyło że p, a q; coś wystarczyło do tego, żeby p i coś ${ }_{a}$ wystarczyło komuś do czegoś ${ }_{b}$ (pozostałe wyrażenia to: coś ${ }_{a}$ wystarczyło na coś, ${ }_{b}$, coś ${ }_{a}$ wystarczyło dla kogośn ${ }_{n}, \cos _{a}$ wystarczyto komuśs na jakiś czas oraz cośs wystarczyło komuśs za cośs).

2. Wyrażenie wystarczy jest traktowane we współczesnych słownikach języka polskiego ${ }^{2}$ oraz w Stowniku syntaktyczno-generatywnym czasowników polskich (SSG) z reguły jako jednostka jednosegmentowa, a jego połączenia z przyimkami przeważnie są interpretowane jako konstrukcje syntaktyczne. W większości analizowanych artykułów hasłowych wystarczy zostaje uznane za jednostkę polisemiczną (szczególny wypadek stanowi tutaj definicja w SWJP, w której badanemu wyrażeniu zostało przyporządkowane tylko jedno znaczenie). Źródła leksykograficzne wyróżniają łącznie cztery znaczenia wystarczy: 1. 'wystąpić w dostatecznej ilości, liczbie, natężeniu itd.; nie brakować' (np.: Godzina wystarczy na przygotowania; Wystarczy mu jednak czasu, żeby jeszcze podszlifować swoje umiejętności); 2. 'stać się przyczyną zaistnienia jakiegoś stanu rzeczy; być dostatecznym powodem' (np.: Wystarczyło jedno spojrzenie, żeby zrozumiat wszystko; Rozumiemy się doskonale, pól słowa wystarczy, aby wiedzieć, co myślimy); 3. 'zastępować kogoś/coś, pełnić funkcję czegoś/kogoś' (np.: Samo jego nazwisko wystarczało za reklame) oraz 4. 'zaspokoić czyjeś potrzeby' (np.: Szukasz sobie dziewczyny, ja ci już nie wystarczam?). W SJPD wyróżniono ponadto jeszcze dwa archaiczne znaczenia wystarczy o odcieniu czynnościowym: 'dawać sobie radę z czym, być w stanie podołać, sprostać czemu' (np. w zdaniach: Dozór ludzi i stajen nawet spadaty na niq i umiała wszystkiemu wystarczyć) oraz 'mieć dosyć (pieniędzy) na co; nastarczyć' (np.: Z niestychanym trudem uczqc się sam i uczqc drugich, ledwie mógł wystarczyć na stancyjkę licha, jadło mizerne).

Już nawet bardzo pobieżna lektura definicji słownikowych pozwala dostrzec dyskusyjność zaproponowanych w nich opisów znaczenia/znaczeń

2 Odwołuję się tutaj do definicji pochodzących ze Słownika języka polskiego pod red. Witolda Doroszewskiego (SJPD), Stownika języka polskiego pod red. Mieczysława Szymczaka (SJPSz), Słownika współczesnego języka polskiego pod red. Bogusława Dunaja (SWJP), Innego słownika języka polskiego pod red. Mirosława Bańki (ISJP), Uniwersalnego słownika języka polskiego pod red. Stanisława Dubisza (USJP) oraz Wielkiego słownika języka polskiego pod red. Piotra Żmigrodzkiego (WSJP). 
leksemu wystarczy, przy czym pomijam tutaj kwestie wynikające z przyjęcia określonych założeń metodologicznych, takie jak m.in. niewłaściwa, w moim odczuciu, delimitacja jednostek języka i, co za tym idzie, uznanie wystarczy za polisemiczną jednostkę jednosegmentową (z taką sytuacją mamy do czynienia w większości słowników). Ze względu na ograniczony rozmiar pracy nie będę w tym miejscu szczegółowo omawiać wszystkich zastrzeżeń, jakie można by wysunąć w stosunku do propozycji leksykografów. Do listy błędów i niedociągnięć dodałabym jednak na pewno: opieranie definicji na błędnych kołach pośrednich (wystarczyć użyte w znaczeniu 'nie brakować' zazwyczaj jest objaśniane w słownikach za pomocą wyrażenia dostateczny, które to z kolei tłumaczy się poprzez odesłanie do pojęcia wystarczania), zły dobór przykładów stanowiących ilustrację materiałową (np. w SJPSz znaczenie 'wystąić w dostatecznej ilości, liczbie, natężeniu itd.; nie brakować' zostało zilustrowane za pomocą zdania: Wystarczyło jedno spojrzenie, żeby zrozumiat wszystko; jakkolwiek w tym konkretnym zdaniu rzeczywiście jest mowa o liczbie spojrzeń, to nie ulega wątpliwości, że pojawienie się tego typu informacji nie jest w żaden sposób uwarunkowane znaczeniem wyrażenia coś wystarczyło, żeby p, por.: Wystarczyło jej gniewne spojrzenie, żeby zrozumiat wszystko; Wystarczyło, że zapadta cisza, żeby zrozumiat wszystko), niepodstawialność zaproponowanych definicji za wystarczy użyte w pierwszym z wyróżnionych znaczeń (por.: Godzina wystarczy na przygotowania - *Godziny nie brakuje na przygotowania; Pieniędzy nie wystarcza mi do końca miesiaca - *Pieniqdze nie wystapity $w$ dostatecznej ilości do końca miesiq$c a$ ), brak informacji na temat łączliwości wystarczy (wyjątek stanowią tutaj artykuły hasłowe pochodzące z ISJP, WSJP oraz, siłą rzeczy, SSG, w których te informacje są podane w sposób eksplicytny; co ciekawe, w tym porównaniu najgorzej wypada SSG, w którym odnotowano najmniej możliwych typów połączeń wystarczy, przy czym warto dodać, że niemal wszystkie z podanych schematów reprezentują konstrukcje eliptyczne), brak informacji lub też szczątkowe wzmianki na temat blokad fleksyjnych nałożonych na wystar$c z y$, uznawanie doraźnie tworzonych konstrukcji składniowych: wystarczy [dość] palcem kiwnqć (SWJP) i wystarczać samemu sobie (SGG), za frazeologizmy, a także, co wydaje się już zupełnie niezrozumiałe, zakwalifikowanie w SJPSz wyrażeń wystarczy [coś zrobić], aby... oraz wystarczy, że coś sie stanie, a (i)... jako „związków terminologicznych”/,związków wyrazowych o charakterze terminologii". 
3. Wbrew temu, co postuluje się w opisach leksykograficznych, sądzę, że wyrażenie wystarczy nie jest jednostką leksykalną, a jedynie elementem współtworzącym kilka monosemicznych jednostek wielosegmentowych. $\mathrm{Na}$ podstawie danych korpusowych, a przede wszystkim własnej intuicji językowej, wyróżniam piętnaście typów kontekstów składniowych charakterystycznych dla elementu wystarczy. Są to, jak następuje:

1. $\mathrm{NP}_{(\mathrm{Nom} .)}+$ wystarczyto, żeby $p / \mathrm{NP}_{(\mathrm{Nom} .)}+$ wystarczyło, żeby $+\mathrm{InfP} /$ wystarczyło + InfP, żeby p/wystarczyło + InfP, żeby + InfP;

2. $\mathrm{NP}_{(\text {Nom.) }}+$ wystarczyło do tego, żeby $p / \mathrm{NP}_{(\text {Nom.) }}+$ wystarczyło do tego, $\dot{z} e b y+\operatorname{InfP}$

3. wystarczyło że p, a q/wystarczyło $+\mathrm{NP}_{(\mathrm{Nom} .)^{\prime}}$ a q/wystarczyło $+\mathrm{InfP}$, aq;

4. $\mathrm{NP}_{(\text {Nom. })}+$ wystarczyto $+\mathrm{NP}_{(\text {Dat. })}+d o+\mathrm{NP}_{(\text {Gen.) }}$;

5. $\mathrm{NP}_{(\mathrm{Gen} .)}+$ wystarczyło, żeby $p / \mathrm{NP}_{(\mathrm{Gen} .)}+$ wystarczyło, żeby + InfP;

6. $\mathrm{NP}_{(\mathrm{Gen} .)}+$ wystarczyło do tego, żeby $\mathrm{p} / \mathrm{NP}_{(\mathrm{Gen} .)}+$ wystarczyło do tego, $\dot{z} e b y+\operatorname{InfP}$

7. $\mathrm{NP}_{\text {(Gen.) }}+$ wystarczyto $+\mathrm{NP}_{(\text {Dat. })}+d o+\mathrm{NP}_{(\text {Gen.) }}$;

8. $\mathrm{NP}_{(\mathrm{Nom} .)}+$ wystarczyto na $\mathrm{NP}_{(\text {Acc. })} / \mathrm{NP}_{(\mathrm{Nom} .)}+$ wystarczyło na to, żeby + InfP/NP ${ }_{(\mathrm{Nom} .)}+$ wystarczyto na to, żeby $p$;

9. $\mathrm{NP}_{(\text {Gen.) }}+$ wystarczyto na $\mathrm{NP}_{(\text {Acc. })} / \mathrm{NP}_{(\text {Gen.) }}+$ wystarczyło na to, żeby + $\operatorname{InfP} / \mathrm{NP}_{(\mathrm{Gen.})}+$ wystarczyto na to, żeby $p$;

10. $\mathrm{NP}_{(\text {Nom. })}+$ wystarczyto dla $+\mathrm{NP}_{(\text {Gen.) }}$;

11. $\mathrm{NP}_{(\mathrm{Gen} .)}+$ wystarczyło dla $+\mathrm{NP}_{(\mathrm{Gen} .)}$;

12. $\mathrm{NP}_{(\text {Nom. })}+$ wystarczyło $+\mathrm{NP}_{(\text {Dat. })}+$ PrepNP/NP ${ }_{(\text {Nom. })}+$ wystarczyto + $\mathrm{NP}_{\text {(Dat.) }}+\mathrm{NP}_{\text {(Inst) }}$;

13. $\mathrm{NP}_{(\text {Gen.) }}+$ wystarczyto $+\mathrm{NP}_{(\text {Dat. })}+$ PrepNP/NP ${ }_{(\text {Gen. })}+$ wystarczyto + $\mathrm{NP}_{\text {(Dat.) }}+\mathrm{NP}_{\text {(Inst) }}$;

14. $\mathrm{NP}_{(\text {Nom.) }}+$ wystarczyto $+\mathrm{NP}_{(\text {Dat. })}+z a+\mathrm{NP}_{(\text {Acc.) }}$;

15. wystarczy $+\mathrm{NP}_{(\mathrm{Gen})}$.

Jak wspomniałam na samym początku, przedmiotem przedstawionych tutaj rozważań będą jedynie jednostki: coś ${ }_{a}$ wystarczyło, żeby p; coś ${ }_{a}$ wystarczyło komuś ${ }_{n}$ do czegoś ${ }_{b}^{3}$; cośs ${ }_{a}$ wystarczyło do tego, żeby $p$ i wystarczyło, że q,

${ }^{3}$ Dosyć często ciąg do w wyrażeniu coś ${ }_{a}$ wystarczyło komuś ${ }_{n}$ do czegoś jest zastępowany przyimkiem dla (np.: Parę stów wystarczy dla opisania, co zaszło potem). Ta 
$a p^{4}$, którym odpowiadają schematy (1)-(7). Podstawę opisu będą stanowiły realizacje schematów opatrzonych numerami (1)-(4). Warianty z genetiwem (schematy (5)-(7)) traktuję nie jako odrębne jednostki języka, ale właśnie jedynie jako warianty ${ }^{5}$, a dokładniej jako strukturalne skróty zdań szerszych, w których podmiotem jest fraza nominalna składająca się z elementu oznaczającego nieokreśloną ilość i rzeczownika w dopełniaczu (argumentacja na rzecz takiej interpretacji w: Wierzbicka 1966).

4. Przed przejściem do części analitycznej pragnę poświęcić jeszcze nieco uwagi wyrażeniu starczy, które - jak sądzę - w wypadku wszystkich badanych jednostek należy uznać za wariant morfologiczny wystarczy. Przemawia za tym fakt, że po pierwsze ciąg ten realizuje dokładnie te same schematy składniowe, co wystarczy, oraz po drugie to, że wzajemne przeciwstawienie w zdaniu odpowiadających sobie jednostek z segmentami starczy i wystarczy sprawia, że otrzymujemy zdanie wewnętrznie sprzeczne, np.:

(1) *Ta tabelka starczy, żebym zmienit zdanie, ale nie wystarczy, żebym zmienit zdanie.

(2) *Ta tabelka wystarczy, żebym zmienit zdanie, ale nie starczy, żebym zmienit zdanie.

tendencja wpisuje się w szersze zjawisko poszerzania zakresu używalności przyimka dla, oceniane przez normatywistów negatywnie (zob. Doroszewski 1982, Miodek 2002).

${ }^{4}$ Jak wskazuje forma gramatyczna segmentu wystarczy pojawiająca się w używanych przeze mnie etykietkach, podstawę opisu będą stanowiły czasowniki w formie dokonanej, zgodnie z negacyjną teorią aspektu Andrzeja Bogusławskiego przyjmuje bowiem, że dokonane formy czasownika są pierwotne pod względem semantycznym wobec ich odpowiedników niedokonanych (Bogusławski 2003). Ponadto zakładam, podobnie jak wspomniany już Bogusławski (por. Bogusławski 2003: 24), że pary aspektowe są wariantami jednej jednostki, a nie, jak chcieliby to widzieć na przykład Zygmunt Saloni i Marek Świdziński (Saloni, Świdziński 1998: 136-137), dwoma zupełnie odrębnymi obiektami językowymi.

${ }^{5}$ Odmiennego zdania są Marek Świdziński i Zygmunt Saloni. Mimo że uważają oni zdania: Pensja starczy mi do dwudziestego i Pensji starcza mi do dwudziestego za semantycznie równoważne, to ze względu na różnice składniowe między nimi przyjmują, że istnieją dwa leksemy: czasownik właściwy STARCZYĆ ${ }^{1}$ i quasi-czasownik STARCZYĆ $^{2}$ (Saloni, Świdziński 1998: 127). Z takim rozwiązaniem polemizuje Maria Szupryczyńska, zarzucająca autorom „,czysto mechaniczne stosowanie kryterium składniowego" (Szupryczyńska 1996: 117). 
(3) *Samo niejedzenie stodyczy starczy do tego, by schudnać do poczatku czerwca, ale nie wystarczy do tego, żeby schudnqć do poczqtku czerwca.

(4) *Samo niejedzenie słodyczy wystarczy do tego, by schudnać do poczatku czerwca, ale nie starczy do tego, żeby schudnać do poczatku czerwca.

Taki sam efekt otrzymamy, przeciwstawiając w zdaniu wyrażenia coś wystarczyło komuś do czegoś i wystarczyło, że q, a p ciagom coś starczyło

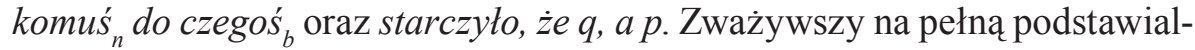
ność obu wyrażeń oraz ich równoznaczność, sądzę, że nie ma powodu, aby opisywać jednostki z segmentem starczy osobno. Wszelkie uwagi, wnioski dotyczące właściwości wyrażeń współtworzonych przez element wystarczy należy zatem uznać za obowiązujące także dla odpowiednich ciągów z segmentem starczyć.

5. Jednostki wystarczyło że q, a p; cośs wystarczyło, żeby $p$; coś ${ }_{a}$ wystarczyło komuś $_{n}$ do czegoś ${ }_{b}$ oraz coś ${ }_{a}$ wystarczyło do tego, żeby $p$ sa predykatami wyższego rzędu przyłączającymi po dwa argumenty nieprzedmiotowe, a w wypadku wyrażenia coś ${ }_{a}$ wystarczyło komuś $_{n}$ do czegoś ${ }_{b}$ - dwa argumenty nieprzedmiotowe i jeden osobowy. Wyrażeniem o najogólniejszym znaczeniu jest w tej grupie ciąg coś ${ }_{a}$ wystarczyło, żeby $p^{6}$ (warianty: coś ${ }_{a} w y$ starczyło, by/aby/izby $p$ ). Lewostronny argument nieprzedmiotowy w zdaniach fundowanych na tym predykacie może być wyrażany przez frazę nominalną w mianowniku lub frazę bezokolicznikową. W wypadku drugiego argumentu nieprzedmiotowego dopuszczalne są wyłącznie frazy zdaniowe i bezokolicznikowe, por:

(5) Nie wystarczy być bogatym, żeby być szczęśliwym.

(6) Nawet moja wyobraźnia nie wystarczy, żeby przewidzieć następstwa tego odkrycia.

(7) Czy to, co pan ustyszat, wystarczyło, żeby pan je zamknat?

${ }^{6}$ Mimo że opisuję badane wyrażenia odrębnie, nie chcę przesądzać istoty ich wzajemnych relacji; nie wykluczam możliwości, że wszystkie te ciągi zostały derywowane na drodze operacji od jednej jednostki leksykalnej. Prawdopodobnie najlepszym kandydatem na operand byłoby tutaj coś ${ }_{a}$ wystarczyło, żeby $p$, właśnie ze względu na swoją prostotę znaczeniową. 
(8) Już sam jej wzrost wystarczy, żeby caly czas zahaczała głowq o żyrandole w różnych pomieszczeniach, a co dopiero, kiedy zatoży szpilki.

(9) Już mały deszcz wystarczy, żeby powstaly kałuże?

5.1. Nieco węższa łączliwość niż coś wystarczyto, żeby $p$ cechuje wyrażenia coś wystarczylo do tego, żeby $p$ (warianty: coś wystarczyto do tego, $a b y / b y / i z b y q$ ) oraz wystarczylo, że q, a p (spójnik $a$ bywa zastępowany również spójnikiem $i$ lub, w wypadku języka mówionego, pauza). W wypadku pierwszego z nich lewostronny argument nieprzedmiotowy może być wyrażany wyłącznie przez frazę nominalną w mianowniku, zaś argument prawostronny - przez frazy zdaniową i bezokolicznikową, por::

7 W drugiej sondzie słownikowej autorstwa Andrzeja Bogusławskiego i Jana Wawrzyńczyka jako osobna jednostka języka zostało zarejestrowane wyrażenie komuśs $_{i} w y$ starczyto charakteru, by (Bogusławski, Wawrzyńczyk 1993: 434). Wyrażenie, ocenione przez autorów jako książkowe, zostało sparafrazowane w następujący sposób: ' $i$ zdobył się na ___ ' Zarówno kształt wyodrębnionej jednostki, jak i zaproponowana definicja znaczenia budzą pewne wątpliwości. Nawet gdyby przyjąć, że przytoczona wyżej parafraza rzeczywiście oddaje znaczenie analizowanego ciągu, to wydaje się, że należałoby uznać, że wyrażenie charakter należy tutaj do wieloelementowej klasy substytucyjnej. Ciagg ten bowiem bez problemu można zastąpić innymi wyrażeniami, takimi chociażby jak odwaga czy - wulgarnie - jaja, por.:

(1) Maurycemu nie wystarczyło charakteru/odwagi/jaj, by powiedzieć, że nie kto inny jak ojciec Ludwika zajmowat się owymi teoriami dla praczek.,

przy czym takie podstawienia nie mają wpływu na znaczenie wyrażenia, tzn. każdy z tych ciągów: komuś $_{i}$ wystarczyto charakterulodwagiljaj, by , można sparafrazować za pomocą definicji zaproponowanej przez autorów hasła. Wydaje się jednak, że problem tkwi właśnie w samej parafrazie, niepotrzebnie wyróżniającej ciąg komuśs ${ }_{i} w y$ starczyto charakteru, by ___ spośród wszystkich użyć tej samej jednostki, por.:

(2) A samemu Rostowskiemu wystarczy inteligencji, by zbić ten zarzut bez uciekania się do obelg?

(3) Czy krakowskim rajcom wystarczy odwagi, aby poprzeć tę inicjatywę?

(4) Przy redukcji pułapu broni konwencjonalnej NATO nie wystarczy wojska, by rozlokować je w Europie.

(5) W tygodniu ledwie czasem wystarczy czasu, żeby przegladnać notatki.

Uznanie wyrażeń argumentowych przyłączanych lewostronnie w zdaniach (1)-(5) za konstrukcje metonimiczne nazywające stany rzeczy (polegające na tym, że czegoś było ileś/ktoś miał czegoś ileś) pozwala interpretować wszystkie powyższe użycia jako realizacje jednej jednostki - coś ${ }_{a}$ wystarczyło, żeby $p$ - i tym samym uniknać niepotrzebnego mnożenia jednostek. 
(10) Podstawowe zwroty, takie jak Good morning, I'm fine, How are you, nie wystarczq do tego, żeby się porozumieć.

(11) Do tego, by obumarty organizm stat się skamieniatościa, nie wystarczy zadziałanie któregokolwiek z omówionych procesów, jeśli nie złaczq się $z$ nim odpowiednie warunki tworzenia osadu.

(12) Tylko kilka czynności wystarczy do tego, żeby komputer opart się atakom wirusów.

(13) Sam kontakt z językiem i słownik majq wystarczyć do tego, by zrozumieć scenkę.

5.2. Argument $q$ wyrażenia wystarczyło, że $q$, a $p$ może być realizowany powierzchniowo przez frazę nominalną w mianowniku, frazę bezokolicznikową oraz frazę zdaniową wprowadzoną spójnikami typu $\dot{z} e$, żeby, gdyby oraz jeśli. Jedyną dopuszczalną realizacją argumentu $p$ jest fraza zdaniowa, por::

(14) Wystarczy, by jeden nerwus puścił salwę, i zacznie się rzeź.

(15) Wystarczy, by wieść o naszym spotkaniu wyszła za te mury, a strace zycie.

(16) Wystarczy, że ktoś ma trudności z parkowaniem, zaraz zjawia się przechodzień i pomaga.

(17) Wystarczy odrobina szarego światta i już muchy obijaja się o szyby.

(18) Wystarczy plotka o tym, że ma nieślubne dziecko, i zaraz usunq go z partii.

(19) Wystarczy, żeby powieka trochę się zagoiła, już lekceważa zabiegi.

(20) Wystarczyło chrzqknqć $i$ wiadomo było, kto jest z kim, a kto przeciw komu, i o co chodzi.

Predykat wystarczyło, że q, a p nakłada pewne ograniczenia semantyczne na przyłączane przezeń wyrażenia argumentowe. Otóż, jak sądzę, oba one muszą nazywać jakieś zdarzenia. Ta hipoteza nie jest kontrowersyjna w wypadku zdań, w których oba argumenty zostały wyrażone za pomocą fraz zorganizowanych wokół czasowników w formie dokonanej czy gerundiów derywowanych od tej formy (przykłady (14)-(15)). Pewne problemy może natomiast sprawiać interpretacja takich zdań, jak przykłady (16)-(19), w których nadawca sygnalizuje zachodzenie jakiejś zmiany w nieco mniej 
standardowy sposób, a mianowicie za pomocą wyrażeń zaraz i już. Usunięcie tych elementów z wyżej wymienionych przykładów sprawia, że otrzymujemy zdania brzmiące gorzej niż zdania wyjściowe (choć nie są to zdania złe), co, jak sądzę, jest spowodowane zatarciem ,punktowości” sytuacji, o których mowa, por.:

(21) ?Wystarczy, że ktoś ma trudności z parkowaniem, zjawia się przechodzień i pomaga.

(22) ?Wystarczy odrobina szarego światta i muchy obijaja się o szyby.

(23) ?Wystarczy plotka o tym, że ma nieślubne dziecko, i usuna go z partii.

(24) ?Wystarczy, żeby trochę powieka się zagoiła, lekceważa zabiegi.

Rzecz jasna, powyższe ciągi nie są jedynymi wyrażeniami, którymi nadawca może się w takim wypadku posłużyć. Co ciekawe jednak, w grę wchodzą tutaj tylko dwa typy wyrażeń. Pierwszy z nich to takie określenia, za pomocą których mówi się, że między dwoma zdarzeniami upłynęło niewiele czasu (np. od razu, natychmiast, wnet). Drugi typ z kolei to wyrażenia, przy użyciu których nadawca dokładnie określa, o jaki odstęp czasu między wydarzeniami chodzi (np. po dwóch tygodniach, do maja), przy czym w danej sytuacji ten konkretny odstęp czasu jest odczuwany przez mówiącego właśnie jako „niewielki”. Oczywiście to, czy nadawca uzna dany odcinek czasu za krótki, zależy tylko od niego, dlatego też „dziwność” zdań (25) i (27) ma moim zdaniem podłoże nie semantyczne, ale pragmatyczne, tzn. wynika z tego, że na podstawie naszej wiedzy o świecie bylibyśmy skłonni sądzić, że taki a taki odstęp czasu w takiej, a nie innej sytuacji należy uznać za długi, a nie - jak sugeruje nadawca - krótki:

(25) ?Wystarczyło, że wyszedt z więzienia, a po dwudziestu latach zacząt rozrabiać.

(26) Wystarczyło, że wyszedt z więzienia, a od razu/po tygodniu/... zacząt rozrabiać.

(27) ?Wystarczy, że pojawi się plotka o tym, że ma nieślubne dziecko, i po dekadzie usuna go z partii.

(28) Wystarczy, że pojawi się plotka o tym, że ma nieślubne dziecko, i natychmiast/w dwa dni/...usuna go z partii. 
Odrębny przypadek stanowi zdanie (20). Podobnie jak w przykładach (16)-(19) nadawca mówi o zdarzeniu w sposób nie do końca standardowy: zdanie wyrażające argument $p$ opisuje stan rzeczy. Ze względu jednak na fakt, że o danym stanie rzeczy mówi się, że zaistniał dopiero w wyniku jakiegoś zdarzenia, wydaje się, że de facto mamy do czynienia z dwoma zdarzeniami: pierwszym, które wywołało przejście od jednego stanu rzeczy w drugi, i z drugim, czyli ze zmianą tego, co było, w to, co nastało w wyniku pierwszego zdarzenia (czyli w tym konkretnym przykładzie nadawca mówi nie tyle, że było coś wiadomo, ile że coś stało się wiadome).

5.2.1. Kwestią, która wymaga jeszcze komentarza, jest status spójników $a$ oraz $i$ łączących wyrażenia argumentowe ciągu wystarczyło, że $q, a p$. Jak już sygnalizowałam, mogą one zostać zastąpione w wypowiedzi pauzą (w wypadku tekstów pisanych: myślnikiem lub przecinkiem), por.:

(29) Wystarczy, by jeden nerwus puścit salwe - zacznie się rzeź.

(30) Wystarczy, by wieść o naszym spotkaniu wyszła za te mury-stracężycie.

(31) Wystarczy odrobina szarego światła, już muchy obijaja się o szyby.

To, czy wyżej wspomniane spójniki są elementami jednostki wystarczyło $\dot{z} e q$, a $p$, nie jest jasne. Fakt, że ciągi te łączą wyrażenia argumentowe przyłączane przez badany predykat, a zatem pojawiają się właściwie wewnątrz struktury jednostki, przemawiałby za uznaniem ich za wariantywne i wymienne z zerem segmenty tej jednostki, natomiast specyficzne ukształtowanie struktury tematyczno-rematycznej zdań konstytuowanych przez wystarczyło że q, a p, właściwe „normalnym” konstrukcjom spójnikowym tego typu (zob. Wajszczuk 1997, 2005) - przeciwnie. W tym artykule przyjmuję, że spójniki $a$ oraz $i$ są elementami jednostki leksykalnej wystarczyło, że $q, a$ $p$, jest to jednak rozwiązanie bardzo robocze i pytanie o status tych ciągów uważam za otwarte.

5.2.2. Kolejną specyficzną właściwością wystarczyło, że q, a p jest brak możliwości zastosowania negacji wewnętrznej w zdaniach fundowanych na tej jednostce, np.:

(32) *Nie wystarczy, by jeden nerwus puścit salwę, i zacznie się rzeź.

(33) Nieprawda, że wystarczy, by jeden nerwus puścit salwe, i zacznie się rzeź. 
(34) *Nie wystarczy plotka o tym, że ma nieślubne dziecko, i zaraz usunq go z partii.

(35) Nieprawda, że wystarczy plotka o tym, że ma nieślubne dziecko, i zaraz usuna go z partii.

Nie obserwujemy tego rodzaju ograniczeń w wypadku zdań zorganizowanych wokół trzech pozostałych jednostek, por.:

(36) Samo napowietrzanie nie wystarczy, aby wyeliminować wszystkie zanieczyszczenia.

(37) Wiem, że sama mitość nie wystarczy do tego, aby zwiazek byt udany!

(38) Jego zdaniem to nie wystarczy do uporzqdkowania granic administracyjnych miasta.

5.3. Jednostką najbardziej złożoną pod względem znaczeniowym spośród badanych predykatów jest coś ${ }_{a}$ wystarczyło komuś ${ }_{n}$ do czegoś $_{b}$. Predykat ten przyłącza trzy argumenty: dwa nieprzedmiotowe oraz jeden osobowy. Wszystkie one mogą być realizowane powierzchniowo wyłącznie przez frazy rzeczownikowe: lewostronny argument nieprzedmiotowy przez frazę nominalną w mianowniku, argument osobowy przez frazę nominalną w celowniku, zaś prawostronny argument nieprzedmiotowy - przez frazę nominalną w dopełniaczu, por:

(39) Omówienie tych kilku par powinno wystarczyć do pokazania istoty pojęcia.

(40) Trzydzieści minut wystarczyło rajcom do opracowania planu.

(41) Te dowody w zupetności wystarczq do procesu poszlakowego.

(42) Czy zeznania już przestuchanych wystarczq do aktu oskarżenia?

Ośrodkami fraz rzeczownikowych wyrażających prawostronny i lewostronny argument nieprzedmiotowy są z reguły gerundia derywowane od form dokonanych czasowników agentywnych ${ }^{8}$ (tak jak w przykładzie (39)). W pozostałych wypadkach, w których te argumenty są realizowane

8 Pojęcia ,czasownik agentywny” używam zgodnie z rozumieniem zaproponowanym przez Izabelę Duraj-Nowosielską w: Duraj-Nowosielska 2007. 
powierzchniowo przez konstrukcje inne niż agentywna, mamy do czynienia z konstrukcjami, które - jak sądzę - należałoby interpretować jako metonimiczne:

(40’) Trzydzieści minut wystarczyło rajcom do opracowania planu. $\rightarrow$ To, co rajcy zrobili przez trzydzieści minut, wystarczyło im [rajcom] do opracowania planu.

(41') Te dowody $w$ zupetności wystarcza do procesu poszlakowego. $\rightarrow$ Przedstawienie tych dowodów w zupełności wystarczy do rozpoczęcia procesu poszlakowego.

(42') Czy zeznania już przestuchanych wystarczq do aktu oskarżenia? $\rightarrow$ Czy to, co zeznali przesłuchani, wystarczy do sformułowania aktu oskarżenia?

O tym, że wyrażenia przyłączane lewostronnie przez badany predykat odsyłają do zdarzeń polegających na tym, że ktoś coś zrobił, przekonują zdania (43), (46), (49), których poprawność budzi pewne wątpliwości:

(43) ?Nagłe załamanie pogody wystarczyto Janowi do odwołania spotkania.

(44) Nagłe załamanie pogody wystarczyło Janowi do tego, żeby odwołać spotkanie.

(45) Nagte załamanie pogody wystarczyło, żeby Jan odwolat spotkanie.

(46) ?Ciagłe szczekanie psa sqsiada wystarczyło Janowi do wezwania policji.

(47) Ciagłe szczekanie psa sqsiada wystarczyło do tego, żeby Jan wezwat policję.

(48) Ciagłe szczekanie psa sqsiada wystarczyło, żeby Jan wezwat policję.

(49) ?To, że Janek wytysiat i przytyl, wystarczyto Marcie do zerwania z nim.

(50) To, że Janek wytysiat i przytyt, wystarczyto Marcie do tego, żeby z nim zerwać.

(51) To, że Janek wylysiat i przytyt, wystarczyło, żeby Marta z nim zerwała.

5.3.1. Pewien szczególny przypadek stanowią zdania, w których jest mowa o tym, że coś wystarczy komuś do szczęścia, petni szczęścia lub życia:

(52) Do szczęścia wystarczy mi rodzina i własny kat. 
(53) Czy Polakowi do szczęścia wystarczy kanapa i telewizor?

(54) Do petni szczęścia wystarczy mi jedynie twoja obecność.

(55) Norwegowi wystarczyło do pelni szczęścia zajęcie piętnastego miejsca $w$ slalomie.

(56) Umiem liczyć, czytać, pisać i to mi wystarczy do życia.

(57) Człowiekowi powinna wystarczyć do życia cela bez okienek i kroplówka wżytę.

Mimo że realizują one dokładnie taki sam schemat składniowy, co przykłady (41) i (42), wydaje się, że mogą być zbudowane na innych jednostkach niż coś $\dot{a}_{a}$ wystarczyło komuśs do czegoś. Za taką interpretacją przemawia fakt, że nie obserwujemy takich ograniczeń semantycznych nałożonych na wyrażenia pojawiające się po lewej stronie ciagu wystarczy, co w wypadku zdań konstytuowanych przez coś ${ }_{a}$ wystarczyło komuś ${ }_{n}$ do czegoś ${ }_{b}$ (por. przykłady (43), (46) i (49)); wyrażenia szczęście, pelnia szczęścia i życie trudno byłoby także uznać za metonimiczne ekwiwalenty konstrukcji agentywnych. Problem sprawia również wskazanie ewentualnej klasy substytucyjnej niezamkniętej wyrażeń, które mogłyby pojawiać się w tej pozycji, por.:

(58) ?Do zadowolenia wystarczy mi rodzina i własny kat.

(59) ?Dobra gra Adama nie wystarczyła do sukcesu w meczu.

(60) ?Do petni zdrowia wystarczy zbilansowana dieta i regularne ćwiczenia.

(61) ?Jednak positki z Bukowej powinny wystarczyć do egzystencji.

Ponadto wyrażenia coś wystarczy komuś do szczesścia i coś wystarczy komuś do życia cechuje swego rodzaju ciągłość: wstawienie jakiegokolwiek wyrażenia między ciąg do a wyrażenie szczęścielżycie powoduje, że powstaje zdanie brzmiące sztuczniej niż zdanie wyjściowe:

(52') ?Do prawdziwego szczęścia wystarczy mi rodzina i własny kat.

(53') ?Czy Polakowi do petnego szczęścia wystarczy kanapa i telewizor?

(56') ?Umiem liczyć, czytać, pisać i to mi wystarczy do spokojnego życia.

(57') ?Człowiekowi powinna wystarczyć do skromnego życia cela bez okienek i kroplówka w żyłę. 
5.3.2. Predykat coś $_{a}$ wystarczyło komuś ${ }_{n}$ do czegos $_{b}$ otwiera jeszcze jedno miejsce argumentowe, a mianowicie miejsce dla wykonawcy czynności, o której mowa w wyrażeniu argumentowym prawostronnego argumentu nieprzedmiotowego. Pozycja ta może, ale nie musi zostać wypełniona na powierzchni: w takim wypadku zrekonstruowanie brakującego elementu nie nastręcza żadnych trudności. Mimo że fraza celownikowa nazywająca agensa pojawia się także w zdaniach konstytuowanych przez pozostałe jednostki, tylko w tym wypadku jest ona rzeczywiście wymagana przez sam predykat - wynika to z ograniczeń semantycznych, o których była mowa wyżej. Jeśli idzie natomiast o frazy celownikowe pojawiające się niekiedy w zdaniach fundowanych na jednostkach coś wystarczyło, żeby $p$ i coś $\dot{s}_{a}$ wystarczyto do tego, żeby $p$, to sądzę, że należy je uznać za predykacje dodane. Na korzyść takiej interpretacji przemawia, po pierwsze, to, że za pomoca tych jednostek nadawca może orzekać o zachodzeniu związku przyczynowo-skutkowego miedzy różnymi zdarzeniami i stanami rzeczy, w tym także takimi, w które nie jest uwikłany żaden agens (por. przykłady (9) i (11)), i, po drugie, to, że nie zawsze fraza celownikowa w zdaniach z tymi jednostkami służy wskazaniu wykonawcy czynności; równie dobrze może ona nazywać beneficjenta, eksperiencera, właściciela jakiejś rzeczy itd., czyli po prostu występować w funkcjach typowych dla celownika, por.:

(62) Czy dobre alibi wystarczy mu do tego, żeby zostać uniewinnionym?

(63) Ja zmadrzałem, wystarczyła mi do tego wymiana zdań z niepetnosprawnym kierowca.

(64) Czy wystarcza nam te dwie godziny, żeby rosót się ugotowat?

(65) Ciężka praca nie wystarczyła mu, żeby otrzymać awans.

5.4. Jak już sygnalizowałam w części poświęconej definicjom słownikowym wyrażenia wystarczy, obserwujemy pewne ograniczenia fleksyjne nałożone na ten ciąg. Wystarczy, jako segment opisywanych jednostek, przeważnie występuje $\mathrm{w}$ formie bezokolicznika lub też $\mathrm{w}$ formie trzeciej osoby obu liczb. Ze względów semantycznych wyrażenie to nie ma formy trybu rozkazującego (zob. Bogusławski 1974), ponadto niemożliwe jest utworzenie od niego imiesłowów przysłówkowych oraz imiesłowu przymiotnikowego biernego. Zdania, w których pojawiają się powyższe formy lub też w których wystarczy występuje w formach innych niż bezokolicznikowa czy formy 
trzeciej osoby, są zbudowane z reguły na innych jednostkach zawierających element wystarczy (np. na cośs wystarczyło komuś ${ }_{n}$ za cośs $_{b}$ lub też na archaicznych jednostkach o odcieniu czynnościowym, które zostały odnotowane w SJPD). Wyjątek stanowią tutaj zdania, w których osoba zostaje jakby uprzedmiotowiona (np.: Czy ja jako wspótwłaściciel wystarczę do załatwienia tej sprawy?), ale trudno byłoby je uznać za przykłady normalnego, nienacechowanego użycia badanych jednostek.

6. Pierwszą, podstawową intuicją odnośnie do znaczeń wyrażeń coś ${ }_{a} w y$ starczyło, żeby $p$; wystarczyło, że $q$, a p; cośs wystarczyło do tego, żeby $p$ oraz coś $_{a}$ wystarczyto komuś ${ }_{n}$ do czegoś jest to, że za ich pomocą nadawca mówi, że coś (jakieś zdarzenie), spowodowało coś innego (jakieś inne zdarzenie). Hipotezę tę potwierdzają następujące przykłady:

(66) *Widok królewskiego pierścienia wystarczyt, żeby ustapit, ale nieprawda, że widok królewskiego pierścienia spowodowat, że ustapit.

(67) *Doskonałe referencje wystarczyły Janowi do tego, żeby zdobyć wymarzona prace, ale nieprawda, że doskonałe referencje Jana spowodowaty, że zdobyt wymarzonq prace.

(68) *Wystarczyto, że dmuchnat w kierunku urzqdzenia, a po chwili wyświetliła się informacja o wyniku, ale nieprawda, że to, że dmuchnat w kierunku urzadzenia, spowodowało, że wyświetlita się informacja o wyniku.

(69) *To, że Jan przez przypadek wynióst dtugopis ze sklepu, wystarczyło Piotrowi do oskarżenia go o kradzież, ale nieprawda, że to, że Jan wynióst dtugopis ze sklepu spowodowato, że Piotr oskarżyt go o kradzież.

Komponent „c o ś a s p o w o d o w a ł o c o ś, będzie powtarzał się (w różnych wariantach, w zależności od ograniczeń znaczeniowych co do łączliwości danego wyrażenia) w eksplikacji każdej z badanych jednostek.

7. Drugim elementem, który, jak sądzę, jest obecny w znaczeniu wszystkich czterech jednostek, jest coś, co można by roboczo nazwać „minimalno-

9 Przegląd koncepcji dotyczących możliwych typów członów relacji przyczynowo-skutkowej można znaleźć przede wszystkim w: Grochowski 1980: $24-27$ (tu także polemika z tezą, że przyczyną może być wyłącznie zdarzenie), a także w: Wierzbicka 1991: 28-44 i Duraj-Nowosielska 2007: 40-57. 
ścią spełnianego warunku". Chodzi tutaj mianowicie o to, że nadawca, używając któregoś z omawianych wyrażeń, chce zakomunikować, że fakt, że między zdarzeniami, stanami itd., o których mowa, istnieje związek przyczynowo-skutkowy, jest czymś niecodziennym; że na podstawie naszej wiedzy o świecie można by sądzić, że z różnych powodów coś $(q)$ nie spowoduje czegoś $(p)$. O tym, że tak jest $\mathrm{w}$ istocie, przekonuje wyraźnie odczuwalna dziwność zdań (70), (72) i (74):

(70) ?Ulewa wystarczy, żeby powstały katuże.

(71) Mały deszcz wystarczy, żeby powstały katuże.

(72) ?Wystarczy ulewa, a już robia się katuże.

(73) Wystarczy mały deszcz, a już robia się katuże.

(74) ?Ścięcie głowy Marii Antoninie wystarczyło do tego, żeby ja zabić.

(75) Kilka gramów orzechów włoskich, na które Jan byt silnie uczulony, wystarczyło do tego, żeby go zabić.

Powyższego testu nie daje się przeprowadzić na zdaniach z coś wystarczyło komuś ${ }_{n}$ do czegoś. ${ }_{b}$. Wynika to z tego, że, jak zauważyła Izabela Duraj-Nowosielska, przypisując komuś predykat agentywny, obarczamy tę osobę odpowiedzialnością za dane zdarzenie, a zatem zakładamy, że mogła ona w jakiś sposób mu zapobiec (Duraj-Nowosielska 2007: 120). Fakt, że nadawca, używając takiej konstrukcji, zawsze przypisuje wykonawcy czynności możliwość wyboru, sprawia, że tak naprawdę nie można mówić o bezwzględnym wynikaniu między dwiema akcjami - ostatecznie przecież nigdy nie jesteśmy w stanie w stu procentach przewidzieć, co ktoś zrobi i czy w ogóle coś zrobi ${ }^{10}$. Sposobem, aby ominąć problem wolnej woli agensa, mogłoby być skonstruowanie takiego zdania, w którym związek przyczynowo-skutkowy zachodziłby nie tyle między jakąś czynnością i reakcją na nią, ile między czynnością a skutkiem czyjegoś działania (podobnie jak w przykładach (74) i (75)). Problem jednak polega na tym, że nawet w wypadku takiego zdania jak:

10 Do podobnych wniosków dochodzi Izabela Duraj-Nowosielska w: Duraj-Nowosielska 2012b: 18 . 
(76) ?Kilka gramów orzechów włoskich, na które Jan byt silnie uczulony, wystarczyło Marii do zabicia go.

to właśnie agens wysuwa się na plan pierwszy; „narzędzie zbrodni” ze zdania (75), orzechy włoskie, w zdaniu (76) staje się jej motywem, powodem, dla którego Maria zabiła Jana (zdanie analogiczne do: Sto złotych wystarczyło temu tajdakowi do zabicia dziadka).

Sygnałem „niepełności” czegoś jako przyczyny czegoś b $_{\mathrm{b}}$ jest także możliwość kookurencji jednostek coś ${ }_{a}$ wystarczyło, żeby p; cośs wystarczyło do tego, żeby $p$ oraz cośs wystarczyło komuśs do czegoś ${ }_{b}$ z takimi wyrażeniami, jak spokojnie ${ }^{11}$, w zupetności, catkowicie, ledwo (por. *coś spokojnie/w zupetności/catkowicielledwo spowodowało...) itp.

(77) Dwa tygodnie ćwiczeń spokojnie wystarcza, bym doszedt do odpowiedniej formy.

(78) Gol Adriana Sikory w zupetności wystarczyt do tego, żeby pokonać Amiki Wronki.

(79) Takie zobowiazanie całkowicie wystarczy do uruchomienia wszystkich procedur.

Ten sens będzie oddany w eksplikacji słowami: „ktoś co wie, mógł być gotów powiedzieć, że coś nie spowoduje czegoś ${ }_{\mathrm{b}}$ ". Pierwszy człon komponentu opiera się na eksplikacji znaczenia a myśli, że p zaproponowanej przez Magdalenę Danielewiczową w pracy Wiedza i niewiedza. Studium polskich czasowników epistemicznych (Danielewiczowa 2002: 332). Szczególnie istotne jest tutaj dla mnie właśnie to - jak to określiła Danielewiczowa - specyficzne ,ustosunkowanie do wiedzy” predykatu a myśli, $\dot{z} e$ p, a konkretniej zawarte $\mathrm{w}$ tej formule przekonanie, że „myśl rodzi się w związku z pewną aktualizowaną wiedzą na dany temat" (Danielewiczowa 2002: 138). Jak próbowałam pokazać przy okazji omawiania przykładów (70)-(76), nadawca, używając którejś z omawianych jednostek, odwołuje się do swojej i odbiorcy wiedzy na temat tego, na ile prawdopodobne jest, że

11 Tezę o implikowaniu przez badane wyrażenia tego, że coś nie jest oczywistym, łatwo przewidywalnym skutkiem czegoś, potwierdzają w pewnym stopniu wnioski, do jakich dochodzi Magdalena Danielewiczowa, analizując znaczenie metapredykatywnego spokojnie (zob. Danielewiczowa 2012: 192). 
dane zdarzenie/stan rzeczy spowoduje inne zdarzenie/stan rzeczy. Orzekając w taki, a nie inny sposób zachodzenie relacji wynikania między nimi, użytkownik wyraźnie sygnalizuje odbiorcy, że ma świadomość tego, że to, co mówi, może się kłócić z jego wiedzą o świecie (choć, rzecz jasna, nie jest w stanie przewidzieć, czy tak jest w istocie; stąd też w formule - być może nie do końca „kompatybilne” z ciągiem byt gotów powiedzieć - wyrażenie mógt).

8. Kolejnym elementem, który w moim przekonaniu powinien znaleźć się w eksplikacjach znaczeń jednostek coś ${ }_{a}$ wystarczyło komuś do czegoś i coś ${ }_{a}$ wystarczyło do tego, żeby $p$, jest informacja o tym, że to, o czym mowa $\mathrm{w}$ wyrażeniu argumentowym przyłączanym prawostronnie, jest w jakiś sposób celowe, jest czymś chcianym ${ }^{12}$, por.:

(80) *Czasami chwila nieuwagi wystarczy do tego, żeby zaprószyć ogieñ ${ }^{13}$.

(81) *Upadek ze schodów wystarczyt do tego, żeby Piotr przez przypadek złamat sobie obojczyk.

(82) *To, że bawit się zapałkami, wystarczyło mu do przypadkowego zaprószenia ognia.

(83) *To, że Kuba mu nieustajaco przeszkadzat podczas gotowania, wystarczyło Janowi do przypadkowego przesolenia sosu.

Bez przeszkód można jednak powiedzieć:

(84) Czasami chwila nieuwagi wystarczy, żeby zaprószyć ogień.

(85) Wystarczy chwila nieuwagi i można zaprószyć ogień.

(86) To, że Kuba podczas gotowania myślat o niebieskich migdałach zamiast skoncentrować się na przepisie, wystarczyło, żeby przez przypadek przesolit sos.

12 To, że pojęcie celu implikuje chcenie, przekonująco pokazał Maciej Grochowski w: Grochowski 1980: 75-76.

13 To zdanie nie byłoby dewiacyjne tylko wtedy, gdyby uznać, że odnosi się ono do dwóch podmiotów: do osoby, która nie uważała, i do kogoś, kto wykorzystał jej roztargnienie do tego, aby (celowo) zaprószyć ogień. 
(87) Wystarczyto, że Kuba zdenerwowat go podczas gotowania, a przez przypadek przesolit sos $^{14}$.

Co ciekawe, nie zawsze jest tak, że owym pożądanym zdarzeniem/stanem rzeczy jest to, o którym mowa w wyrażeniu argumentowym pojawiającym się po prawej stronie wyrażenia predykatowego. Dosyć często, zwłaszcza w wypadku ciągu coś ${ }_{a}$ wystarczy komuś ${ }_{n}$ do czegoś, można odnieść wrażenie, że jakieś zdarzenie (coś $)$ jest tylko pretekstem dla kogoś, żeby zrobić $\operatorname{coś}_{\mathrm{b}}$; że mamy do czynienia $\mathrm{z}$ rodzajem wnioskowania, $\mathrm{w}$ którym pominięto jakąś przesłankę, por.:

(88) To, że Jan przez przypadek wynióst dtugopis ze sklepu, wystarczyło Piotrowi do oskarżenia go o kradzież, mimo że Piotr wiedział, że Jan zrobit to przez przypadek.

(89) To, że Jan przez przypadek wynióst dtugopis ze sklepu, wystarczyło Piotrowi do tego, żeby oskarżyć go o kradzież, mimo że Piotr wiedziat, że Jan zrobit to przez przypadek.

(90) To, że dziadek zgubit klucze, wystarczyło wnukom do przetrzaśnięcia domu staruszka.

(91) To, że dziadek zgubił klucze, wystarczyło wnukom do tego, żeby przetrzasnać dom staruszka.

Jakkolwiek dwa ostatnie z powyższych zdań mogą budzić pewne wątpliwości co do swojej poprawności, sądzę, że ich dziwność wynika tylko z tego, że w ich wypadku trudniej jest wskazać kontekst uspójniający, ową brakującą przesłankę. I tak, dla zdań (88) i (89) może być nią na przykład chęć Piotra, aby skompromitować Jana przed Marią. W wypadku przykładów (90) i (91) rzeczywistą przyczyną przeszukania domu dziadka może być plotka o niebotycznym bogactwie staruszka i chęć wnuków, żeby sprawdzić, ile w tych pogłoskach prawdy.

Jak już sygnalizowałam, z tego rodzaju sytuacją - wrażeniem nieadekwatności przyczyny do skutku w zdaniach z $\operatorname{coś}_{a}$ wystarczyło komuśs do

14 O związku wyrażeń przypadkiem, przez przypadek, niechcacy z pojęciem intencjonalności pisała Izabela Duraj-Nowosielska w: Duraj-Nowosielska 2012a, 2012b oraz 2012c. 
czegoś $_{b}$ i $\cos _{a}$ wystarczyto do tego, żeby $p$ - mamy do czynienia często, ale nie zawsze; ten problem pojawia się właściwie wyłącznie w wypadku zdań opisujących działania jakichś agensów. Dlatego też wydaje się, że nie ma podstaw do tego, aby uznać, że „pretekstowość” czegoś tkwi w samych znaczeniach analizowanych jednostek. Raczej interpretowałabym ją jako ,efekt zderzenia" konstrukcji agentywnej, informacji o czyjejś chęci, aby stało się to, co się stało (por. przykłady (88)-(91)), z sensem, który roboczo nazwałam „minimalnością spełnianego warunku”. Mając to wszystko na uwadze, proponuję, aby informację o tym, że to, o czym mowa w wyrażeniu argumentowym przyłączanym prawostronnie, jest czymś pożądanym, oddać w obu eksplikacjach słowami: „ktoś 1 chciał czegoś co zostało przed chwilą powiedziane, coś może, ale nie musi być tożsame z czymś ; to, czy tak jest, zależy od tego, czy coś jest ostatecznym celem kogoś $_{n}$, czy też tylko środkiem do jego osiągnięcia). Kilku słów wyjaśnienia wymaga tutaj samo wyrażenie $k t o s_{\text {, }}$ a dokładniej to, do kogo może się ono odnosić w tym kontekście. Wydaje się, że desygnatem może być tutaj niemal każdy: począwszy od wykonawcy czynności, o której mowa w prawostronnym wyrażeniu argumentowym, przez nadawcę wypowiedzi czy bliżej nieokreśloną społeczność, aż po Istotę Najwyższą (taka interpretacja może nasuwać się na przykład w wypadku zdań orzekających zachodzenie zależności przyczynowo-skutkowej między zdarzeniami/stanami rzeczy w świecie przyrody, por. przykłady (9) i (11)).

9. Na sam koniec pragnę powrócić jeszcze do problemu, który został już częściowo omówiony, a mianowicie do implikacji zawartej w wystarczyło, że $q$, a p, że między dwoma zdarzeniami, o których mowa w zdaniu, upłynęło niewiele czasu (por. przykłady (39)-(42)). Ze względu na fakt, że za pomocą coś ${ }_{a}$ wystarczyło, żeby $p$ i coś ${ }_{a}$ wystarczyło do tego, żeby p można orzekać o relacji przyczynowo-skutkowej, w której przyczyną jest stan, w wypadku tych jednostek można odrzucić podobną hipotezę. Świadczą o tym zdania (92)-(95), w których nie zostaje przesądzone, czy dane zdarzenie lub stan rzeczy spowodowane przez stan, o którym mowa w lewostronnym wyrażeniu argumentowym, nastąpiło krótko czy długo po nim, por.:

(92) Nawet moja wyobraźnia nie wystarczy, żeby przewidzieć następstwa tego odkrycia. 
(93) Już sam jej wzrost wystarczy, żeby cały czas zahaczała głowq o żyrandole $w$ różnych pomieszczeniach, a co dopiero, kiedy założy szpilki.

(94) Sama jego reputacja wystarczyła do tego, żeby otwieraty się przed nim każde drzwi.

(95) To wszystko, czego się o nim dowiedziałem podczas naszych dtugoletnich podróży, wystarczy mi do tego, żeby zawsze mówić o nim dobrze.

Inaczej jest, jeśli idzie o wyrażenie coś ${ }_{a}$ wystarczyło komuśs do czegoś ${ }_{b}$. W wypadku zdań, w których coś ${ }_{\mathrm{b}}$ jest znacznie odsunięte w czasie w stosunku do czegoś, mamy podobną sytuację jak w przykładach (88) i (90): zaczynamy poszukiwać jakiegoś dodatkowego połączenia między czymś oraz czymśs, prawdziwej, bezpośredniej przyczyny zdarzenia, o którym mowa. Te poszukiwania mogą pójść w dwóch kierunkach: albo przyjmiemy, że nadawca pominął jakiś oczywisty element wnioskowania, albo że to, co ktoś zrobił, jest czynnością złożoną i że członem w relacji wynikania jest de facto jakaś faza danej czynności, a nie ona sama pojmowana jako całość, por.:

(96) Plotka o jego nieślubnym dziecku wystarczyła do usunięcia go z partii po dekadzie.

(97) To drobne przewinienie Jana z czasów młodości wystarczyło doświadczonemu adwokatowi do podważenia jego wiarygodności jako świad$k a$, mimo że całe zajście miało miejsce lata temu i Jan bardzo się od tego czasu zmienit.

(98) Podparcie Platońskiej koncepcji selektywnego rozmnażania teoria doboru naturalnego Darwina wystarczyło do uzyskania po wielu dekadach szerokiego poparcia tej idei wśród sfer akademickich.

Jak sądzę, z pierwszym przypadkiem, tzn. założeniem, że przedstawione w zdaniu wnioskowanie jest niekompletne, możemy mieć do czynienia w zdaniach (96) i (97). W wypadku tego pierwszego bezpośrednią przyczyną usunięcia z partii osoby, o której mowa w zdaniu, może być na przykład to, że plotka dotarła do uszu prezesa (krążyła już ona między ludźmi przez dziesięć lat, zanim ktoś mu ją powtórzył). Jeśli idzie o zdanie (97), to tutaj brakująca przesłanką może być to, że adwokat podzielił się z sędzią informacją 
na temat tego, co Jan zrobił w młodości ${ }^{15}$. Przykład (98) reprezentuje z kolei prawdopodobnie drugi typ wyjaśniania, tzn. odbiorca zakłada, że jedna z czynności, o których mowa, w tym wypadku uzyskiwanie poparcia pośród dużej grupy ludzi, jest procesem długotrwałym i złożonym. Oczywiście można by w tym miejscu wysunąć zarzut, że zdarzenia, o których mowa w zdaniach (96)-(98) same w sobie są złożone, a zatem że takie, a nie inne wyniki testu są, mówiąc wprost, kwestią samego testu. Problem jednak polega na tym, że w wypadku zdarzeń dotyczących ludzi nie sposób przewidzieć, co konkretnie może stanowić motyw czyjegoś działania; zawsze przecież bezpośrednią przyczyną tego, że ktoś coś zrobi, może być jakieś przeżycie wewnętrzne, uzmysłowienie sobie czegoś, jakaś retrospekcja itd. Ze względu na złożoność ludzkiej psychiki nie jest możliwe wskazanie zamkniętego zbioru przeżyć, które mogą wywołać daną reakcję, dlatego też poszukiwanie ostatecznej, obiektywnej przyczyny, dla której ktoś coś zrobił, jest z góry skazane na niepowodzenie.

Ten sens zostanie oddany w eksplikacjach znaczeń wystarczyło, że q, a $p$ i coś ${ }_{a}$ wystarczyło komuśs do czegośs słowami: „,coś ${ }_{\mathrm{a}}$ stało się krótko po czymśs" (w różnych wariantach).

10. Poniżej przedstawiam moje propozycje eksplikacji znaczeń wyrażeń coś ${ }_{a}$ wystarczyło, żeby p; coś ${ }_{a}$ wystarczyło do tego, żeby p; coś ${ }_{a}$ wystarczyło komuś $_{n}$ do czegoś ${ }_{b}$ oraz wystarczyło, że q, a p:

coś ${ }_{a}$ wystarczyto, żeby $p^{16}$

coś spowodowało coś

ktoś ze względu na to, co wie, mógł być gotów powiedzieć, że coś nie spowoduje czegoś

15 Wydaje się, że podważanie tego, co ktoś mówi, jest nierozerwalnie związane z mówieniem (nawet jeśli ktoś pokaże komuś materialny dowód tego, że ktoś nie ma racji lub kłamie, to i tak nie powiemy o kimś, że podważył to, co ktoś mówi, dopóki ktoś nie wskaże związku między danym obiektem a całą sprawą), dlatego też sądzę, że przykład (97) reprezentuje po części także drugi typ wyjaśniania.

16 Zmienne zdaniowe $p$ i $q$ zarówno w wypadku wyrażenia cośs wystarczyło, żeby $p$, jak i coś ${ }_{a}$ wystarczyło do tego, żeby $p$ oraz wystarczyło, że q, a p odpowiadają zdarzeniom/stanom rzeczy, które w definiensie oznaczane są za pomocą ciągów coś $(q)$ i cośs $(p)$. 
coś ${ }_{a}$ wystarczyło do tego, żeby $p$

coś spowodowało coś

ktoś $\hat{k}_{\mathrm{k}}$ ze względu na to, co wie, mógł być gotów powiedzieć, że coś nie spowoduje czegoś

ktoś ${ }_{1}$ chciał czegoś

coś $_{a}$ wystarczyło komuś ${ }_{n}$ do czegoś

$\operatorname{coś}_{\mathrm{a}}$, co ktoś $\mathrm{m}_{\mathrm{m}}$ zrobił, spowodowało coś ${ }_{\mathrm{b}}$, co zrobił ktoś ${ }_{\mathrm{n}}^{17}$

ktoś zrobił coś $_{\mathrm{b}}$ krótko po tym, jak ktoś zrobił coś $_{\mathrm{a}}$

ktoś ${ }_{\mathrm{k}}$ ze względu na to, co wie, mógł być gotów powiedzieć, że to, co ktoś zrobił, nie spowoduje tego, że ktoś zrobi coś $_{\mathrm{b}}$

ktoś chciał czegoś $_{\mathrm{c}}$

wystarczyło, że q, a p

to, że stało się cośs, spowodowało, że stało się coś

$\operatorname{coś}_{\mathrm{b}}$ stało się krótko po czymśs

ktoś $\hat{k}_{\mathrm{k}}$ ze względu na to, co wie, mógł być gotów powiedzieć, że to, że stało się coś ${ }_{\mathrm{a}}$, nie spowoduje tego, że stanie się $\cos _{\mathrm{b}}^{18}$

Por. zdania:

(99) Już mały deszcz wystarczy, żeby powstaty kałuże.

'mały deszcz spowoduje, że powstaną kałuże

ktoś ze względu na to, co wie, mógł być gotów powiedzieć, że mały deszcz nie spowoduje, że powstaną kałuże'

${ }^{17}$ Kimś ${ }_{\mathrm{m}}$ i kimś może być ta sama osoba, por.: W środę w Krakowie zwycięzcę wytoniła dogrywka, ale wczoraj nawet dodatkowy czas gry nie wystarczyt zawodnikom do przechylenia szali zwycięstwa na swoja korzyść; Kuettel nie zmarnowat okazji i skoczyt 129,0 m - to wystarczyło mu do pokonania Austriaka.

18 Aby zastosować wyżej zaproponowane formuły do parafrazy zdań konstytuowanych przez formy niedokonane badanych jednostek, należy dokonać drobnej modyfikacji, a mianowicie zastąpić formy dokonane predykatu coś spowodowało, że p formami niedokonanymi (różnica znaczeń między tymi formami, sprowadzająca się do przeciwstawienia: pojedyncze zdarzenie - prawidłowość, odpowiada różnicy, jaką obserwujemy między formami dokonanymi i niedokonanymi opisywanych jednostek). 
(100) To, że dziadek zgubit klucze, wystarczyło wnukom do tego, żeby przetrzqsnać dom staruszka.

'to, że dziadek zgubił klucze, spowodowało, że wnuki przetrząsnęły jego dom

ktoś ze względu na to, co wie, mógł być gotów powiedzieć, że to, że dziadek zgubił klucze, nie spowoduje tego, że wnuki przetrząsną jego dom

[wnuki chciały znaleźć pieniądze dziadka]'

(101) Przedstawienie przez prokuraturę nowych dowodów w zupetności wystarczyło do rozpoczęcia przez sad procesu poszlakowego.

'to, że prokuratura przedstawiła nowe dowody, spowodowało, że sąd rozpoczął proces poszlakowy

sąd rozpoczął proces poszlakowy krótko po tym, jak prokuratura przedstawiła nowe dowody

ktoś ze względu na to, co wie, mógł być gotów powiedzieć, że to, że prokuratura przedstawiła nowe dowody, nie spowoduje tego, że sąd rozpocznie proces poszlakowy

[ktoś chciał, żeby rozpoczął się proces poszlakowy]'

(102) Wystarczy, że pies zaszczeka, a ona już biegnie na druga strone ogrodu.

'to, że pies zaszczeka, spowoduje, że ona pobiegnie na drugą stronę ogrodu

to, że ona pobiegnie na drugą stronę ogrodu, wydarzy się krótko po tym, jak pies zaszczeka

ktoś ze względu na to, co wie, mógł być gotów powiedzieć, że to, że pies zaszczeka, nie spowoduje, że ona pobiegnie na drugą stronę ogrodu'

Formułując eksplikacje znaczeń badanych jednostek, starałam się używać jeśli nie wyrażeń prostych, to przynajmniej prostszych od definiendum. Spośród użytych przeze mnie wyrażeń za proste uznawane są ktoś robi coś/ ktoś robi coś z czymś (Bogusławski 1991, 2007), ktoś (Bogusławski 2007), ktoś wie o czymś, że coś; nie: coś (Bogusławski 2007) oraz coś się stało (Bogusławski 1972; Stanisław Karolak w artykule O semantyce aspektu za wyrażenie reprezentujące pojęcie zmiany w sposób dyskretny uznał predykat STAĆ SIĘ, przy czym podał go właśnie w takiej formie, bez wskazywania otwieranych przezeń miejsc walencyjnych; Karolak 1996). Kandydatem na 
indefinibile, a w każdym razie jednostką stosunkowo prostą jest także wyrażenie ktoś jest gotów powiedzieć, że p (Danielewiczowa 2002). Ponadto warto wspomnieć, że pojęcia KTOŚ, CHCIEĆ, ROBIĆ, KRÓTKO/KRÓTKI CZAS oraz PO znajdują się na liście indefinibiliów Anny Wierzbickiej (Wierzbicka 2006).

\section{Bibliografia}

Apresjan J., 1995, Semantyka leksykalna. Synonimiczne środki języka, tłum. Z. Kozłowska, A. Markowski, Wrocław-Warszawa-Kraków: Zakład Narodowy im. Ossolińskich.

BAŃKo M. (red.), 2000, Inny stownik języka polskiego, t. 1-2, Warszawa: PWN.

BogusŁaWski A., 1972, O wyrażeniach oznaczających zmianę, w: A. Wierzbicka (red.), Semantyka i stownik, Wrocław: Ossolineum, s. 147-149.

BogusŁawski A., 1974, O rozkaźniku, Prace Filologiczne, t. 25, s. 191-198.

BogusŁawski A., 1976, O zasadach rejestracji jednostek języka, Poradnik Językowy, z. 8, s. 356-364.

BogusŁawski A., 1991, Semantic primes for agentive relations, Lingua Posnaniensis XXXII-XXXIII, s. 39-64.

BogusŁawski A., 1998, Preliminaria gramatyki operacyjnej, tłum. R. Gozdawa-Gołębiowski, Polonica XIII, s. 163-223.

BogusŁawski A., 2003, Aspekt i negacja, Warszawa: Katedra Lingwistyki Formalnej UW.

BogusŁawski A., 2007, A Study in the Linguistics-Philosophy Interface, Warszawa: BEL Studio.

Bogustawski A., Danielewiczowa M., 2005, Verba polona abscondita. Sonda stownikowa III, Warszawa: Elma Books.

BogusŁawski A., Wawrzyńczyk J., 1993, Polszczyzna, jaka znamy. Nowa sonda stownikowa, Warszawa: Katedra Lingwistyki Formalnej UW.

Danielewiczowa M., 2002, Wiedza i niewiedza. Studium polskich czasowników epistemicznych, Warszawa: Katedra Lingwistyki Formalnej UW.

Danielewiczowa M., 2012, W głab specjalizacji znaczeń. Przystówkowe metapredykaty atestacyjne, Warszawa: BEL Studio.

Doroszewski W. (red.), 1958-1969, Stownik języka polskiego, t. 1-11, Warszawa: Państwowe Wydawnictwo „Wiedza Powszechna”, Państwowe Wydawnictwo Naukowe.

Doroszewski W. (red.), 1982, Stownik poprawnej polszczyzny PWN, Warszawa: Państwowe Wydawnictwo Naukowe. 
DuBIsz S. (red.), 2003, Uniwersalny stownik języka polskiego, t. 1-4, Warszawa: Wydawnictwo Naukowe PWN.

Dunas B. (red.), 1996, Słownik współczesnego języka polskiego, Warszawa: Wydawnictwo Wilga.

DuraJ-Nowosielska I., 2007, Robić coś $i$ coś powodować: opozycja agentywności i kauzatywności w języku polskim, Warszawa: Wydział Polonistyki UW.

Duraj-Nowosielska I., 2012a, Kilka uwag o wpływie przycisku zdaniowego na interpretację przysłówków-modyfikatorów intencjonalności (na przykładzie niechcacy, przypadkiem), Linguistica Copernicana 1 (7), s. 113-138.

Duraj-Nowosielska I., 2012b, Nie przypadkiem o niechcący. Szkic semantyczny, Warszawa: Wydawnictwo UKSW.

Duraj-Nowosielska I., 2012c, O (tajemniczej) roli intencjonalnego działania w zdaniach z przysłówkiem ,przypadkiem”, Linguistica Copernicana 2 (8), s. 127-171.

Grochowski M., 1980, Pojęcie celu: studia semantyczne, Wrocław: Ossolineum.

KAROLAK S., 1996, O semantyce aspektu (w dwudziestą rocznicę publikacji rozprawy F. Antinucciego i L. Gebert „Semantyka aspektu czasownikowego”), Biuletyn Polskiego Towarzystwa Językoznawczego 52, s. 9-56.

Miodek J., 2002, Stownik ojczyzny polszczyzny, Wrocław: Wydawnictwo Europa.

PolAŃSKi K. (red.), 1992, Stownik syntaktyczno-generatywny czasowników polskich, t. 5, Wrocław: Ossolineum.

SAloni Z., Świdziński M., 1998, Składnia wspótczesnego języka polskiego, Warszawa: Państwowe Wydawnictwo Naukowe.

SzUPRYCZyŃSKa M., 1996, Pozycja sktadniowa frazy celownikowej $w$ zdaniu polskim, Toruń: Top Kurier.

SzymcZaK M. (red.), 1978-1981, Stownik języka polskiego, t. 1-3, Warszawa: Państwowe Wydawnictwo Naukowe.

Wasszczun J., 1997, System znaczeń w obszarze spójników polskich. Wprowadzenie do opisu, Warszawa: Katedra Lingwistyki Formalnej UW.

Wajszczuk J., 2005, O metatekśsie, Warszawa: Katedra Lingwistyki Formalnej UW.

Wierzbicka A., 1966, Czy istnieją zdania bezpodmiotowe, Język Polski XLIV, s. $177-196$.

Wierzbicka A., 2006, Semantyka: jednostki elementarne $i$ uniwersalne, przekł. A. Głaz, K. Korżyk, R. Tokarski, Lublin: Wydawnictwo UMCS.

WierzBicka E., 1991, Synonimia składniowa konstrukcji przyczynowo-skutkowych we współczesnej polszczyźnie, Warszawa: Wydawnictwo UW.

ŻMigrodzki P. (red.), 2012-..., Wielki stownik jezzyka polskiego, [online:] http://wsjp.pl/. 


\section{The semantic-syntactic analysis \\ of the chosen lexical units with the word wystarczy \\ (summary)}

The paper presents the results of the analysis of the following lexical units with the word wystarczy: coś ${ }_{a}$ wystarczyło, żeby $p ;$ coś ${ }_{a}$ wystarczyło do tego, zeby $p ;$ coś wystarczyło komuś ${ }_{n}$ do czegos $s_{b}$; wystarczyło, ze q, a p. On the basis of the analysis of their valency and the conducted tests, the author states that all these lexical items imply that an event/a state of affairs caused another event/state of affairs and that someone, basing on their knowledge about the world, could think that this would not have happened. Further research has proven that two of those lexical units $\cos _{a}$ wystarczyto komuś do czegoś $\dot{s}_{b}$ and coś wystarczyto do tego, żeby p - imply, moreover, that an event/a state of affairs, caused by another event/state of affairs, was somehow desired. It has also turned out that the speaker using coś ${ }_{a}$ wystarczyto komuś $_{n}$ do czegoś ${ }_{b}$ or wystarczyło, że q, a p, informs that the resultant event/state of affairs occurred right after the causative event/state of affairs. 
